\title{
Bronchodilators for treatment of mild bronchiolitis: a factorial randomised trial
}

\author{
Elaine E L Wang, Ruth Milner, Upton Allen, Helen Maj
}

\begin{abstract}
A randomised double blind trial was conducted to determine the efficacy of inhaled bronchodilators, salbutamol and ipratropium bromide, compared with placebo in the treatment of bronchiolitis. Patients, who were 2 months to 2 years of age and without underlying cardiac or pulmonary disease, received drug 1 (salbutamol or saline placebo) followed one hour later by drug 2 (ipratropium bromide or placebo). Both agents were administered every four hours. The patients were allocated to one of four groups according to a factorial design. The four groups were similar in demographic characteristics, initial oxygenation, and clinical score. The change in oxygen saturation of recipients of both agents was significantly better than that of recipients of salbutamol alone or ipratropium bromide alone. This change, however, was not statistically different from that of the control group. No difference was observed in the clinical score or hospital duration. Inhaled bronchodilators did not improve the condition of hospitalised mild bronchiolitis.
\end{abstract}

Bronchiolitis is a major cause of morbidity in young infants. Because of similar clinical findings between bronchiolitis and asthma, and because half of all bronchiolitics go on to develop reversible airway disease, numerous investigators have examined the efficacy of bronchodilators in this patient population. ${ }^{1-8}$ For the most part these studies did not find any benefit from bronchodilators. However, they have been criticised because patients needed to be sedated for the tests, which also resulted in the tests being performed during the convalescent rather than the acute phase of illness. More recently three double blind randomised studies conducted in the emergency room found bronchodilators to be effective as measured with a clinical score ${ }^{10}$ or pulse oximetry and measures of respiratory rate and retractions. "

This study was conducted to examine the efficacy of inhaled bronchodilators in hospitalised patients using pulse oximetry and clinical score. Observer agreement for these measures had previously been assessed in a similar patient population. ${ }^{12}$ There was very good agreement for assessments of pulse oximetry and moderate agreement for those of clinical assessment.

Patients and methods

The study was carried out at the Hospital for Sick Children in Toronto, Canada. This 600 bed facility is the referral hospital for central and southern Ontario as well as the main paediatric hospital serving Toronto, a municipality of 2.5 million people. The usual practice for treatment of bronchiolitis in the emergency department at this hospital has been to administer two to three treatments of salbutamol by inhalation. Infants who 'respond' are discharged on a variety of oral medications, most commonly orciprenaline. Infants with an 'inadequate response' are admitted to hospital. Before commencement of the study over $90 \%$ of hospitalised patients were treated with inhaled salbutamol.

All patients aged 2 months to 2 years hospitalised for the first time with bronchiolitis were eligible for the study, except if they had known underlying cardiac or pulmonary disease, they had been transferred from another hospital, their condition was rapidly deteriorating, or the parents or attending physicians refused their participation in the study. Thus, all patients admitted into this study did not have adequate improvement with emergency department management which always included salbutamol. Bronchiolitis was diagnosed by the attending paediatrician on the ward in the presence of expiratory wheezing of acute onset accompanied by signs of viral illness such as coryza. ${ }^{13} 14$ The study was approved by the human subjects review committee at the hospital.

Patients were stratified into two groups: those 6 months of age or less and those older than 6 months, because of previous observations of poorer prognosis in young infants. ${ }^{15-17}$ Patients were then randomised into one of four groups in a factorial design. Patients all received drug 1 , which consisted of salbutamol (Ventolin, Glaxo) or normal saline placebo, followed by drug 2, which was ipratropium bromide (Atrovent, Boehringer Ingelheim) or normal saline, one hour later. All treatments were administered over 15 to 20 minutes by face mask and Whisperjet nebuliser (Marquest Medical Products) driven by oxygen at a flow rate of 6-7 1/minute. Both drugs 1 and 2 were repeated every four hours for the duration of hospitalisation or three days whichever came first. One group received salbutamol at $0.15 \mathrm{mg} / \mathrm{kg} /$ dose $(0.03 \mathrm{ml} / \mathrm{kg} / \mathrm{dose})$ in $2 \mathrm{ml}$ of saline followed one hour later by $0.5 \mathrm{ml}$ or $1 \mathrm{ml}$ of saline placebo. A second received $0.03 \mathrm{ml} / \mathrm{kg}$ of saline in $2 \mathrm{ml}$ of saline followed by either $125 \mu \mathrm{g}(0.5 \mathrm{ml})$ of ipratropium bromide if less than 6 months or $250 \mu \mathrm{g}(1 \mathrm{ml})$ of ipratropium bromide if older than 6 months. A-third group received both salbutamol and ipratropium bromide in the doses indicated. The final group received saline 
placebos in the same volumes indicated. The contents of drug 1 and 2 were not indicated on the supplies sent to the ward and only the pharmacy staff were aware of the allocation until the code was broken at the conclusion of the study.

A nasopharyngeal swab was obtained from both nostrils for immunofluorescence assay for detection of respiratory syncytial virus, influenza, parainfluenza, and adenovirus antigens. ${ }^{18}$ The same specimen was used for isolation of respiratory viruses and enteroviruses on green monkey kidney, Graham's 293, and Hep 2 cell lines.

Oxygen saturation was measured on admission and again on the later of two days: the discharge day or day 3 if the patient remained in hospital. The value was determined after monitoring children in an awake non-crying state for 10 minutes using pulse oximetry (Nellcor). Additionally, in order to avoid effects of bronchodilator, patients were assessed during the longer of the two intervals between bronchodilators, just before drug 1 was administered. In three patients, oxygen supplementation was discontinued 10 minutes before measurement of oxygen saturation. No other patients were receiving oxygen supplementation at the time of evaluation. The day 3 measurement was selected because it was the median length of stay of our patients with bronchiolitis. Patients were graded for severity with respect to respiratory rate, retractions, wheezing, and general condition (table 1) on admission and discharge or day 3. This score was adapted from one that has previously been used in studies of childhood reactive airway disease including bronchiolitis. ${ }^{19}$ Patients were assessed by study personnel (EELW and HM) who were blinded to the treatment allocation on enrolment and on discharge or the third hospitalisation day if the patient was still in hospital. Interobserver agreement had previously been demonstrated for these investigators. ${ }^{12}$ In addition, the research nurse (HM) visited daily and was informed of any untoward events.

Comparability between the four intervention groups was assessed using $\chi^{2}$ analysis for proportions of Kruskal-Wallis analysis for enrolment oxygen saturation and clinical score, which were not normally distributed.

The primary outcome was the change in oxygen saturation and severity score between admission and day 3. For patients discharged before day 3, the discharge values were considered to be the same as day 3 values. A two way analysis of variance was used to determine the independent effects of salbutamol and ipratropium bromide as well as their interaction on the change scores and hospital duration. ${ }^{20}$

\section{Results}

Between 4 January 1988 and 30 June 1989, 342 patients were hospitalised with bronchiolitis. Of these, 192 were ineligible, 40 were missed when the study team were not called, and 48 were not enrolled because parents refused to consent to the study. Thus 62 infants were enrolled in the study.

Respiratory syncytial virus was identified by immunofluorescence or viral isolation from 16 of 60 patients $(27 \%)$ in whom the virology laboratory received an adequate specimen. No other viral agents were recovered.

There was no difference between groups in the gender or age distribution, the frequency of family history of atopy, prior use of bronchodilators, or identification of a causative organism by $\chi^{2}$ analysis $(\mathrm{p}>0.01$, table 2$)$. However, relatively fewer boys appeared to have been randomised to receive placebo. Similarly, no difference in the enrolment oxygen saturation or clinical score was observed using Kruskal-Wallis analysis $(\mathrm{p}>0 \cdot 10)$.

A significant difference was observed within the four treatment groups for their effect on change in oxygenation $(\mathrm{F}=8.96, \mathrm{p}=0.004$; fig 1). The change in oximetry of the recipients of both salbutamol and ipratropium bromide was significantly better than in those receiving salbutamol alone $(\mathrm{F}=10 \cdot 24, \mathrm{p}=0.002)$ and ipratropium bromide alone $(\mathrm{F}=4 \cdot 14, \mathrm{p}=0 \cdot 04)$. However, the mean change in oxygen saturation with both agents was not significantly different from that in the placebo control group $(F=0 \cdot 8$, $\mathrm{p}>0 \cdot 1)$. The poorer response with salbutamol

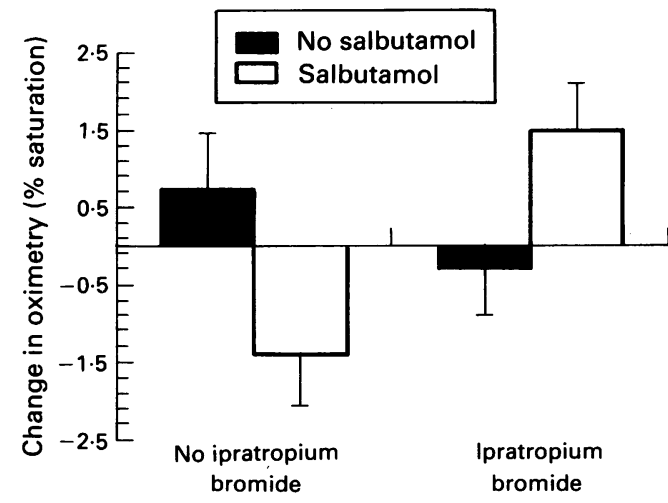

Figure 1 Change in oxygen saturation by treatment group. Results are mean $(S E)$.

Table 1 Definition of categories for clinical assessment

\begin{tabular}{|c|c|c|c|c|}
\hline & \multicolumn{4}{|l|}{ Score } \\
\hline & 0 & $I$ & 2 & 3 \\
\hline $\begin{array}{c}\text { Respiratory rate } \\
\text { (breaths/min) }\end{array}$ & $\leqslant 30$ & $30-45$ & $46-60$ & $>60$ \\
\hline Wheezing & None & $\begin{array}{l}\text { Terminal expiration } \\
\text { or only with } \\
\text { stethoscope }\end{array}$ & $\begin{array}{l}\text { Entire expiration } \\
\text { or audible on } \\
\text { expiration without } \\
\text { stethoscope }\end{array}$ & $\begin{array}{l}\text { Inspiration and } \\
\text { expiration without } \\
\text { stethoscope }\end{array}$ \\
\hline & None & Intercostal only & Tracheosternal & $\begin{array}{l}\text { Severe with } \\
\text { nasal flow }\end{array}$ \\
\hline General condition & Normal & & & $\begin{array}{l}\text { Irritable/lethargic/poor } \\
\text { feeding }\end{array}$ \\
\hline
\end{tabular}


Table 2 Comparability of groups for demographic characteristics, prezious bromchodilator use, viral recozery, initial oxvgen saturation, and clinical score

\begin{tabular}{|c|c|c|c|c|}
\hline & $\begin{array}{l}\text { Salbulamol } \\
\text { and ipratropium } \\
\text { hromide }\end{array}$ & $\begin{array}{l}\text { Salhuuamol } \\
\text { omly }\end{array}$ & $\begin{array}{l}\text { Ipratropium } \\
\text { bromidi omly. }\end{array}$ & $\begin{array}{l}\text { Sulme } \\
\text { placibus }\end{array}$ \\
\hline $\operatorname{Sex}(M / F)$ & $9: 8$ & 86 & $11+$ & 610 \\
\hline \multicolumn{5}{|l|}{ Age (months) } \\
\hline 6 & 8 & 6 & 6 & 6 \\
\hline 8 & 9 & 8 & y & 10 \\
\hline \multicolumn{5}{|l|}{ Family history of atopv } \\
\hline Yes & 7 & 4 & 7 & 8 \\
\hline No & 10 & 10 & 8 & 7 \\
\hline \multicolumn{5}{|l|}{ Previous use of bronchodilators } \\
\hline Yes & 3 & 1 & 3 & t \\
\hline No & 14 & 13 & 12 & 12 \\
\hline \multicolumn{5}{|l|}{ Causative organism } \\
\hline Respiratory svncvtial virus & 5 & 4 & + & 3 \\
\hline None & 12 & 9 & 11 & 12 \\
\hline \multicolumn{5}{|l|}{ Initial median oxven } \\
\hline Saturation (1\%) & 96 & $96 \cdot 5$ & 97 & 96.5 \\
\hline Range & $86-99$ & $9+100$ & $93 \cdot 100$ & 92100 \\
\hline Initial median clinical score & 5 & 5 & + & \\
\hline Range & $2-9$ & (i) -8 & $1-6$ & $3-11$ \\
\hline
\end{tabular}

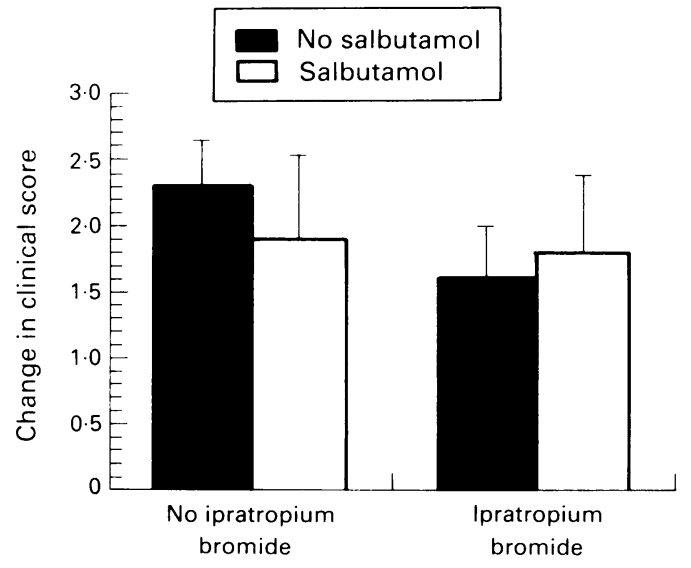

Figure 2 Change in clinical score by treatment group. Results are mean (SE).

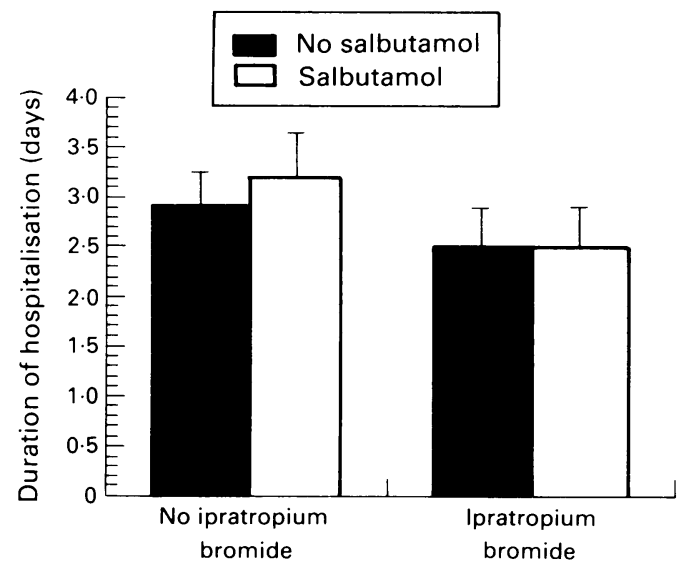

Figure 3 Duration of hospitalisation by treatment group. Results are mean (SE).

was also significant when compared with the control $(F=4 \cdot 81, p=0 \cdot 03)$. No significant difference was observed for either agent or the combination on clinical score or hospitalisation compared with placebo (figs 2,3). In fact, the mean clinical score improved the most in the placebo recipients (fig 2 ). The distribution of oxygen saturation change according to the day of final assessment is displaved in fig 4 . Again, there was no significant difference among the study groups.

Four patients had worsening of their disease. Two patients had received both active agents: one was transferred to the intensive care unit for respiratory support after receiving the first dose of each medication and the other was placed on tribavirin (ribavirin) because of cyanosis and respiratory distress. A third patient, subsequently found to be in the control group, deteriorated after the first mask and was placed on continuous salbutamol. Finally, one patient who was allocated to the salbutamol alone group developed increasing respiratory distress and was started on systemic steroids and theophylline. One additional patient, receiving salbutamol only, was withdrawn after three days in the study because of tremulousness after the medication.

\section{Discussion}

There continues to be controversy about the use of bronchodilators in the management of bronchiolitis. A recent survey conducted of 21 paediatric allergists and pulmonologists indicated that the majority would use bronchodilators in bronchiolitis. ${ }^{21}$ This occurred despite the fact that current textbooks do not recommend these agents for this condition. ${ }^{2-}$ Older studies measuring pulmonary function tests before and after bronchodilators observed no improvement with bronchodilators. $10 \times 23$ However, because of the necessity of sedation in order to obtain these measurements, the patients were not in the acute phase of their disease. ${ }^{24}$ The validity of these pulmonary function tests have also been questioned. ${ }^{25}$ One study in intubated patients has observed a $43 \%$ improvement in maximum expiratory flow rate suggesting that bronchodilator treatment is useful in the acute phase of disease. ${ }^{26}$ Also, more recently studies conducted in the emergency room have concluded that inhaled salbutamol $^{10} 11$ and subcutaneous adrenaline" are efficacious at least in the short term in these settings. However, the number of return visits or admissions were not reported. One possible explanation for the contradictory result is that there are two clusters of patient responses. Soto and coworkers observed that $30 \%$ of their patient population had improved conductance after bronchodilators whereas the rest had not. ${ }^{27}$

Because of the usual practice at our study hospital, the patients who were enrolled in this study had mild bronchiolitis as demonstrated by their oxygen saturation and clinical score on admission. However, in this population of patients with mild disease, there was no benefit in using bronchodilators. When either agent was used alone, the oximetry actually decreased compared with admission values in contradistinction to the group that received both active agents and the control group. The benefit of combining these agents over using the agents singly has been shown in asthma and chronic obstructive pulmonary disease treatment. $2 x$ in

Tal and coworkers found improvement only 


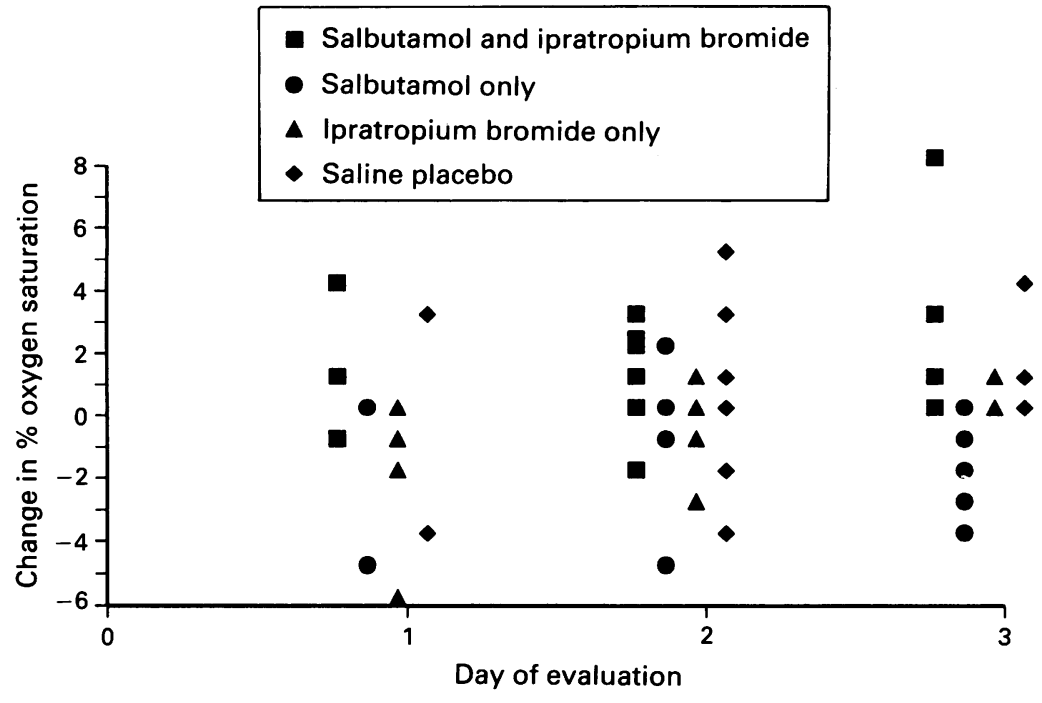

Figure 4 Change in \% oxygen saturation according to day of final evaluation.

in infants treated with both salbutamol and dexamethasone. ${ }^{7}$ However, average daily clinical scores, arterial carbon dioxide and oxygen tensions, and duration of hospitalisation were not significantly different for the salbutamol group compared with those not receiving salbutamol. Stokes et al observed an improvement in work of breathing with ipratropium bromide but not with salbutamol. ${ }^{5}$ This caused Henry and coworkers to study the clinical efficacy of ipratropium bromide compared with saline placebo in 66 infants as determined by parental and nursing staff assessments. ${ }^{1}$ The daily improvement in clinical score suggested to the authors that the measurements were sensitive to change. The number of treatments required were similar between the two groups. No benefit from ipratropium bromide was observed in this study.

The difference in our conclusions compared with studies conducted in emergency department settings ${ }^{9-11}$ may be because the study outcomes were taken days after hospitalisation. The objective of the study was to determine whether there would be an effect of the drugs on improving the condition of hospitalised children with possible reduction in hospital stay rather than the short term effect of these agents as seen in the emergency room. Furthermore, our study population consisted of those patients who failed to show an adequate improvement to allow them to be discharged from the emergency department. It is possible that those patients with bronchiolitis who respond to bronchodilators are not hospitalised.

Although the small study size may have limited the power to detect differences, the negative effect of salbutamol on oximetry measurement and the small magnitude of the differences observed in the study makes it highly unlikely that bronchodilators are effective in the patient population studied.

Of concern was the observation of untoward effects in patients in this study. The study was not designed to have adequate power to detect differences in complication rates such as requirement for ventilatory support or tribavirin because of their infrequent occurrence. However, our data do not suggest that these agents can prevent these serious events. In addition, one of the younger infants developed severe enough tremulousness to warrant discontinuation of salbutamol by the attending physician, suggesting that bronchodilators are not totally benign agents. This observation and the decline in pulmonary function with salbutamol observed in ours and previous studies ${ }^{4} 31$ emphasises the need for caution in prescribing bronchodilators for this illness.

We did not find that bronchodilators improved oxygen saturation or clinical score enough to result in shorter hospitalisation in patients with mild bronchiolitis. Decisions on using these agents must be based on their short term benefit which, although statistically significant, amounted to a mean improvement of only $2 \%$ in oxygen saturation." 1 The use of either salbutamol or ipratropium bromide in the treatment of patients hospitalised with mild bronchiolitis cannot be recommended.

We thank Drs Peter Liu and Ronald Gold for their careful review of the manuscript. We also thank Dr Martin Petric and the virology department for viral identification, the attending physicians and nurses on ward $7 \mathrm{D}$, and the parents and children who participated in the study.

This study was supported by research grant 02172 from the Ontario Ministry of Health. Dr Allen was an Eli Lilly fellow in paediatric infectious disease at the time of the study.

1 Henry RL, Milner AD, Stokes GM. Ineffectiveness of ipratropium bromide in acute bronchiolitis. Arch Dis Child 1983;58:925-6.

2 Lenney W, Milner AD. Alpha and beta adrenergic stimulants in bronchiolitis and wheezy bronchitis in children under 18 in bronchiolitis and wheezy bronchitis in childr
months of age. Arch Dis Child 1978;53:707-9.

3 Lenney W, Milner AD. At what age do bronchodilator drugs work? Arch Dis Child 1978;53:532-5.

4 O'Callaghan C, Milner AD, Swarbrick A. Paradoxical deterioration in lung function after nebulised salbutamol in wheezy infants. Lancet 1986; ii: 1424-5.

5 Stokes GM, Milner AD, Hodges IGC, Henry RL, Elphick MC. Nebulised therapy in acute severe bronchiolitis in infancy. Arch Dis Child 1983;58:279-83.

6 Rutter N, Milner AD, Hiller EJ. Effect of bronchodilators on respiratory resistance in infants and young children with bronchiolitis and wheezy bronchitis. Arch Dis Child 1975; 50:719-22.

7 Tal A, Bavilski C, Yohai D, Bearman JE, Gorodischer R, Moses SW. Dexamethasone and salbutamol in the treatment of acute wheezing in infants. Pediatrics 1983;71:13-8.

ment of acute wheezing in infants. Pediatrics 1983;71:13-8.
8 Phelan PD, Williams HE. Sympathomimetic drugs in acute viral bronchiolitis. Their effect on pulmonary resistance. Pediatrics 1969;44:493-7.

9 Lowell DI, Lister G, Koss HV, McCarthy P. Wheezing in infants: the response to epinephrine. Pediatrics 1987;79: 939-45.

10 Klassen TP, Rowe PC, Sutcliffe T, Rapp L, McDowell IW, $\mathrm{Li}$ MM. Randomized trial of salbutamol in acute bronchiolitis. F Pediatr 1991;118:807-11.

11 Schuh S, Canny G, Reisman JJ, et al. Nebulized albuterol in acute bronchiolitis. $\mathcal{F}$ Pediatr 1990;117:633-7.

12 Wang EEL, Milner RA, Navas L, Maj H. Observe agreement for respiratory signs and oximetry in infants hospitalised with lower respiratory infections. Am Rev Respir Dis (in press)

13 Henry R, Milner AD, Stokes GM. Bronchiolitis. Am 7 Dis Child 1983;137:806.

14 McConnochie K. Bronchiolitis: what's in a name? Am f Dis Child 1983;137:11-3.

15 McMillan JA, Tristram DA, Weiner LB, Higgins AP, Sandstrom C, Brandon R. Prediction of the duration of infection: use of clinical parameters. Pediatrics $1988 ; 81$ : 22-6.

16 Green $M$, Brayer AF, Schenkman KA, Wald ER. Duration of hospitalization in previously well infant with respiratory hospitalization in previously well infant with respiratory

17 Lebel MH, Gauthier M, Lacroix J, Rousseau E, Buithieu M. Respiratory failure and mechanical ventilation in severe Respiratory failure and mechanical ventilation

18 American Public Health Association. Diagnostic procedures for viral, rickettsial and chlamydial infections. 5 th Ed. Washington: American Public Health Association, 1979.

19 Bierman CW, Pierson WE. The pharmacologic management of status asthmaticus in children. Pediatrics 1974;54:245. 
20 Kleinbaum DG, Kupper LL. Two way ANOVA with unequal cell numbers. Applied regression analysis and unequal cell numbers. Applied regression analysis and other multin $351-75$.

21 Newcomb RW. Use of adrenergic bronchodilators by pediatric allergists and pulmonologists. Am $\mathcal{J}$ Dis Child 1989;143. 481-5.

22 Behrman RE, Vaughan VCI, eds. Nelson textbook of pediatrics. 12th Ed. Philadelphia: W B Saunders, 1983

23 Seidenberg J, Masters IB, Hudson I, Olinsky A, Phelan PD. Effect of ipratropium bromide on respiratory mechanics in infants with acute bronchiolitis. Australian Paediatri Fournal 1987;23:169-72.

24 Mallol J, Sly PD. Effect of chloral hydrate on arterial oxygen saturation in wheezy infants. Pediatr Pulmonol 1988:5: Satura. 9 .

25 Mallol J, Hibbert ME, Robertson CF, Olinsky A, Phelan $P D$, Sly PD. Inherent variability of pulmonary function PD, Sly PD. Inherent variability of pulmonary function 1988;5:152-7.
26 Mallory GB, Motoyoma EK, Koumbourlis AC, Mutich RI, Nakayama DK. Bronchial reactivity in infants in acute Nakayama DK. Bronchial reactivity in infants in acute respiratory failur

27 Soto ME, Sly PD, Uren E, Taussig LM, Landau L.I. Bronchodilator response during acute viral bronchiolitis in infancy. Pediatr Pulmonol 1985;2:85-90.

28 Gross NJ. Ipratropium bromide. $N$ Engl f Med 1988:319: 486-94.

29 Beck R, Robertson C, Galdes-Sebaldt M, Levison $H$. Combined salbutamol and ipratropium bromide by inhalation in the treatment of severe acute asthma. $\mathcal{7}$ Pediatr 1985;107:605-8.

30 O'Driscoll BR, Taylor RJ, Horsley MG, Chambers DK, Bernstein A. Nebulised salbutamol with and without ipratropium bromide in acute airflow obstruction. Lancet 1989;i:1418-20.

31 Hughes DM, Lesouef PN, Landau LI. Effect of salbutamol on respiratory mechanics in bronchiolitis. Pediatr Res 1987;22:83-6.

AIDS in Romania

One of the most emotionally draining pieces of writing, fact or fiction, I have ever read is the article about AIDS in Romania published in the Lancet on 14 September (Bradley S Hersh and colleagues, Lancet 1991;338:645-9). As a testament to the depths of the pit which human beings are capable of digging for themselves it can have had few equals since the writings of George Orwell and Aldous Huxley and the more graphic accounts of the holocaust or the killing fields of Cambodia. Not that the article is written in anything other than proper, factual, scientific style; it isn't, but the facts themselves are harrowing.

Romania is a country of 23 million people. In the year after the death of Ceaucescu 1168 cases of AIDS were reported to the Ministry of Health and $94 \%$ of those were children under 13 years, almost all (99\%) less than 4 years old. Nearly two thirds of them had been abandoned by their parents and were living in public institutions. How did they get AIDS? Not, it seems, from their mothers, for only $8 \%$ of tested mothers were HIV positive. A very small number $(0.5 \%)$ of the children had received blood products for clotting disorders but $39 \%$ of them had been given transfusions of unscreened blood. Most (57\%) of them appear to have got the disease through the repeated use of inadequately sterilised needles and syringes in their orphanages and 'dystrophic centres'. At the time of the demise of the regime there were 14000 children less than 4 years old in orphanages and 2500 chronically ill or malnourished children in those revoltingly named centres. A serological survey of 12231 children showed that $10 \%$ were HIV positive. In the orphanages it was $8 \%$ and in the centres $22 \%$. In one district nearly half of the children in the institutions were HIV positive.

Why? Why did parents abandon their children? Were the parents themselves victims of the regime or had they simply been indoctrinated to believe that the responsibility was not theirs but the state's and that the state would provide? I am reminded of an incident on my own unit when a young couple were asked by a nurse if they would like to feed their baby and replied, 'No, that's your job' and went for a walk round the hospital grounds while it was done. A relatively minor incident and not to be compared with the much larger canvas, but what do we know about the infectivity of depravity? How is it that one apparently depraved monster can infect society with his own depravity?

It's possible to wax philosophical at some length about these things. I shall resist the temptation. But why? Why, why, why, why ....? 